On the taxonomic status of the enigmatic Phycolepidoziaceae (Marchantiophyta: Jungermanniales) with description of a new species, Phycolepidozia indica

Gradstein, S Robbert ; Laenen, Benjamin ; Frahm, Jan-Peter ; Schwarz, Uwe ; Crandall-Stotler, Barbara J ; Engel, John J ; Von Konrat, Matthew ; Stotler, Raymond E ; Shaw, Blanka ; Shaw, A Jonathan

DOI: https://doi.org/10.12705/633.17

Posted at the Zurich Open Repository and Archive, University of Zurich ZORA URL: https://doi.org/10.5167/uzh-98380

Journal Article

Published Version

Originally published at:

Gradstein, S Robbert; Laenen, Benjamin; Frahm, Jan-Peter; Schwarz, Uwe; Crandall-Stotler, Barbara J; Engel, John J; Von Konrat, Matthew; Stotler, Raymond E; Shaw, Blanka; Shaw, A Jonathan (2014). On the taxonomic status of the enigmatic Phycolepidoziaceae (Marchantiophyta: Jungermanniales) with description of a new species, Phycolepidozia indica. Taxon, 63(3):498-508.

DOI: https://doi.org/10.12705/633.17 


\title{
On the taxonomic status of the enigmatic Phycolepidoziaceae (Marchantiophyta: Jungermanniales) with description of a new species, Phycolepidozia indica
}

\author{
S. Robbert Gradstein, ${ }^{1 *}$ Benjamin Laenen, ${ }^{2 *}$ Jan-Peter Frahm, ${ }^{3 \dagger}$ Uwe Schwarz, ${ }^{4}$ Barbara J. Crandall-Stotler, ${ }^{5}$ \\ John J. Engel, ${ }^{6}$ Matthew von Konrat, ${ }^{6}$ Raymond E. Stotler, ${ }^{5 \dagger}$ Blanka Shaw ${ }^{7}$ \& A. Jonathan Shaw ${ }^{7}$ \\ 1 Museum National d'Histoire Naturelle, Department Systématique et Evolution, C.P. 39, 57 Rue Cuvier, 75231 Paris 05, France \\ 2 Institut für Systematische Botanik, Universität Zürich, Zollikerstrasse 107, 8008 Zürich, Switzerland \\ 3 Nees Institut für Biodiversität der Pflanzen, Universität Bonn, Meckenheimer Allee 170, 53111 Bonn, Germany \\ 4 Prestige Grand Oak 202, 7th Main, 1st Cross, HAL IInd Stage, Indira Nagar, Bangalore 560038, India \\ 5 Department of Plant Biology, Southern Illinois University, Carbondale, Illinois 62901-6509, U.S.A. \\ 6 Department of Botany, The Field Museum, Chicago, Illinois 60605-2496, U.S.A. \\ 7 Department of Biology, Duke University, Durham, North Carolina 27708, U.S.A. \\ * contributed equally to this paper \\ Author for correspondence: S. Robbert Gradstein,gradstein@mnhn.fr
}

DOI http://dx.doi.org/10.12705/633.17

\begin{abstract}
The monospecific Phycolepidoziaceae with the single neotropical species Phycolepidozia exigua is a highly specialized leafy liverwort without vegetative leaves. The extreme reduction of morphological and anatomical characters of Phycolepidozia has caused uncertainties as to the systematic position of the genus and family. In 2012, a second species of Phycolepidozia was detected in the Western Ghats, South India. The Indian plant differs from P. exigua in several respects and is described here as $P$. (subg. Metaphycolepidozia) indica Gradst., J.-P.Frahm \& U.Schwarz. Differences include the massive stem of $P$. indica, the larger perianth with a crenate, 3-lobed mouth, and the epidermis of the capsule wall made up of non-tiered cells with nodular thickenings on both longitudinal and transverse walls. A phylogenetic analysis using four different chloroplast regions ( $p s b A$, $p s b T, r p s 4, r b c L)$ of $P$. indica and putatively related groups shows that Phycolepidozia is nested within the leafy liverwort family Cephaloziellaceae. Consequently, Phycolepidoziaceae is placed in the synonymy of Cephaloziellaceae. The discovery of $P$. indica adds a further example to the list of amphi-Pacific tropical disjunctions in bryophytes.
\end{abstract}

Keywords amphi-Pacific tropical disjunction; Cephaloziellaceae; leafless stems; liverworts; molecular phylogeny; Phycolepidozia; taxonomy; Western Ghats

Supplementary Material The alignment is available in the Supplementary Data section of the online version of this article at http://www.ingentaconnect.com/content/iapt/tax

\section{INTRODUCTION}

The genus Phycolepidozia R.M.Schust. (Marchantiophyta: Jungermanniales) is a unique, alga-like leafy liverwort, differing from all known liverworts by having stems and branches without leaves and underleaves but with leafy gametoecia. The genus is monospecific, containing the single species $P$. exigua R.M.Schust. from the Neotropics (Schuster, 1966). Schuster assigned Phycolepidozia to a separate family, Phycolepidoziaceae R.M.Schust., because its characters did not fit any other family. He considered affinities of Phycolepidozia to Cephaloziellaceae, Cephaloziaceae and Lepidoziaceae but excluded it from the latter two families because of the highly reduced seta consisting of only eight rows of cells (four rows of large epidermal cells surrounding four rows of minute inner cells). From Lepidoziaceae the genus differs further by the scattered rhizoids and elaters with tapered ends. By its seta structure Phycolepidozia is similar to Cephaloziellaceae, the reduced $4+4$ seta being diagnostic of this family. Nevertheless, Schuster (1966) considered a close affinity of Phycolepidozia to Cephaloziellaceae "improbable" because of its very thin, leafless stems and the ciliate perianth mouth, and he suggested that the cephalozielloid seta of Phycolepidozia was a homoplastic character.

Phycolepidoziaceae have since been accepted as a separate family by all authors (e.g., Fulford, 1968; Crandall \& al., 2009) with the exception of Gradstein \& al. (2001) who united Phycolepidoziaceae with Lepidoziaceae. Its single species, Phycolepidozia exigua, was collected in 1966 by the late Dr. Rudolf M. Schuster on the island of Dominica where it was found growing on tree trunks in humid rainforest at ca. $450 \mathrm{~m}$. Attempts to recollect $P$. exigua in the type locality, or elsewhere, have long been unsuccessful and the species has been redlisted as "Critically Endangered" (Schäfer-Verwimp, 2010; Hallingbäck, 2013). A second locality of the species (based on

Received: 29 Sep 2013 | returned for revisions: 7 Nov 2013; 27 Nov 2013; 8 Feb 2014 | revisions received: 24 Nov 2014; 16 Jan 2014 ; 8 Feb 2014 | accepted: 8 Feb 2014 | not published online ahead of inclusion in print and online issues || (C International Association for Plant Taxonomy (IAPT) 2014 
a 25-year-old herbarium specimen) has recently been discovered on Cerro Duida in the Guayana Highland of Venezuela (Gradstein, in press).

Surprisingly, a new species of Phycolepidozia differing from $P$. exigua in several important respects was collected by one of us (US) in the Western Ghats, South India, in November 2012. Because of the puzzling morphology of the genus and uncertainties about the status of the family Phycolepidoziaceae, we employed DNA sequences to explore its phylogenetic relationships. Several genomic regions of leafy liverworts have recently been sequenced and have given important new insights in the intricate phylogenetic relationships within this large group of plants (see Crandall-Stotler \& al., 2009, for review). In this study we have employed different chloroplast DNA loci, which are very important and straight-forward sources of information for phylogenetic inference at generic and family level in liverworts (e.g., Stech \& Quandt, 2010). By sequencing four chloroplastic regions of Phycolepidozia and comparing the recovered sequences with those of putatively related groups, we assessed the relationships of this enigmatic liverwort.

\section{MATERIALS AND METHODS}

Relationships of Phycolepidozia and of the family Phycolepidoziaceae were investigated using sequence data from the material of the new species from India. DNA was extracted using the DNeasy Plant Minikit (Qiagen Benelux B.V., Venlo, The Netherlands). Four chloroplast regions ( $p s b A, p s b T, r p s 4$, $r b c L)$ were amplified following the protocol described in Laenen \& al. (2011). The four loci were concatenated and aligned to six accessions (genera) of the unpublished "Liverwort Tree of Life" database (LiToL; http://biology.duke.edu/bryology/ $\mathrm{LiToL} /$ ) and to 29 accessions from GenBank, using the program Seaview v.4.4.2 (Gouy \& al., 2010). The additional accessions were chosen based on putative relationships of Phycolepidoziaceae (Schuster, 1966). Gaps were inserted when necessary to achieve character homology and scored as missing data. We used maximum likelihood (ML) and parsimony (MP) analysis for phylogenetic analysis of the data. Maximum likelihood analysis was performed using the program RAxML-HPC v.7.0.4 (Liu \& al., 2011) on the Cipres data portal (Miller \& al., 2009). A fifty percent majority-rule consensus tree was built based on one thousand bootstrap replicates using the GTRCAT model and the rapid bootstrapping option. Parsimony analysis was done using PAUPRat (Sikes \& Lewis, 2001) on the Cipres data portal. Heuristic searches with 10,000 random taxon replicates were conducted with tree-bisection-reconnection (TBR) branch-swapping. Characters were equally weighted. We also conducted a bootstrap analysis with 100 replicates and 10 random starting points, using the TBR option. A consensus tree was built from the equally best trees retained during the heuristic search and compared to the ML consensus tree for detecting potential disagreement.

\section{RESULTS}

\section{Description of the new species}

Phycolepidozia indica Gradst., J.-P.Frahm \& U.Schwarz, sp. nov. - Holotype: INDIA. Western Ghats, Karnataka State, Coorg District, trail to the summit of Mount Tandiandamol, $25.9 \mathrm{~km} \mathrm{SSW}$ of Madikeri, $1610 \mathrm{~m}$, on a shaded

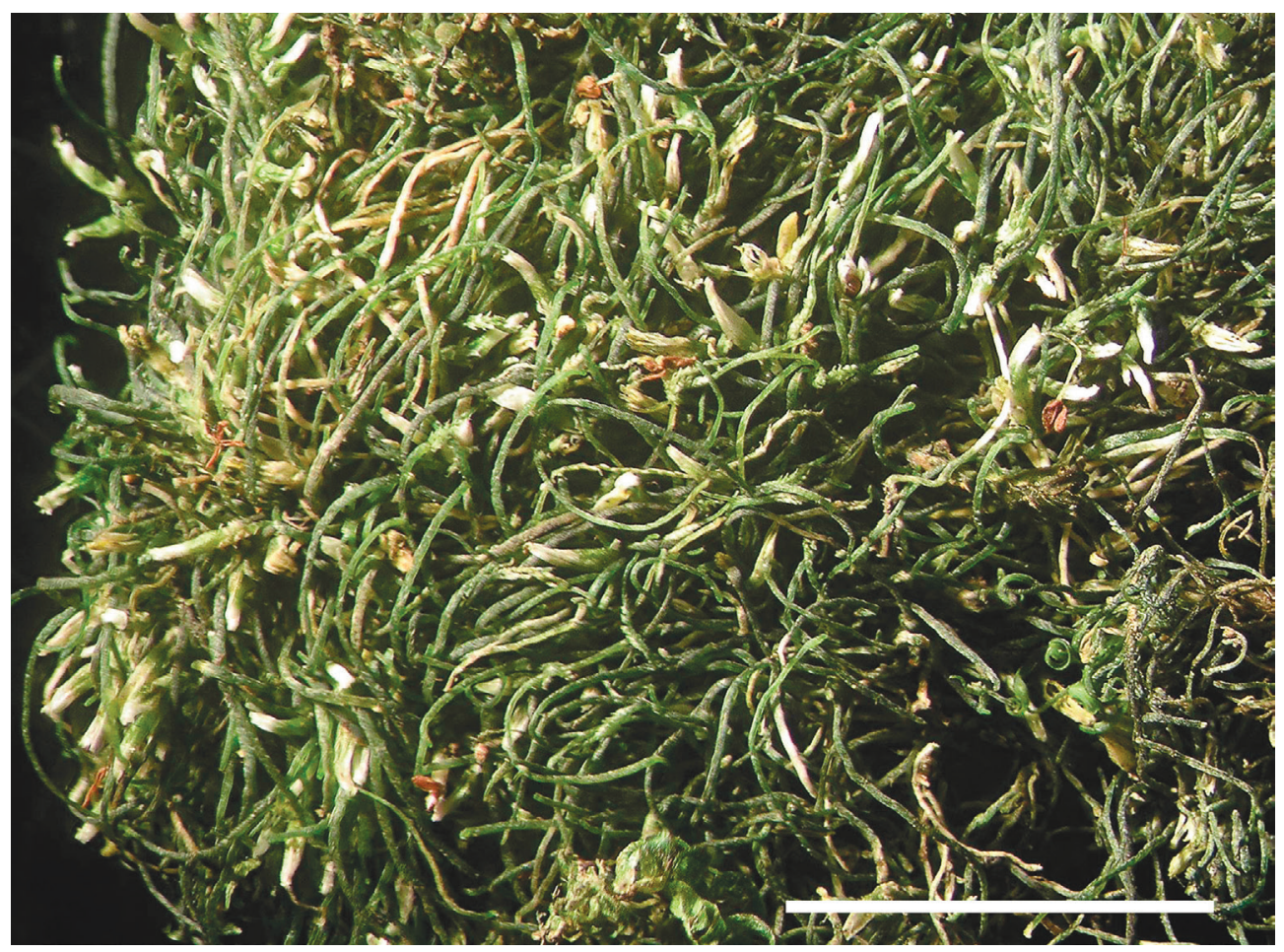

Fig. 1. Habit of Phycolepidozia indica. - Scale: $1 \mathrm{~cm}$. 
rock in remnant forest along the trail, $75^{\circ} 36^{\prime} 34.20^{\prime \prime} \mathrm{E}$, $12^{\circ} 13^{\prime} 14.68^{\prime \prime}$ N, 11 Nov. 2012, U. Schwarz, J.-P. Frahm \& F. Schumm s.n. (PC!; isotypes: LWG!, hb. Schwarz 10659!).

Morphological description (Figs. 1-2). - Autoicous. Plants forming small, bristle-like greenish mats on rock, consisting of short, creeping rhizomes giving rise to ascending leafless shoots to $8 \mathrm{~mm}$ long, without leaves and underleaves but with leafy gametoecia on short branches. Stems irregularly branched, pale green when young, deep green when mature, turning blackish-green when dry, up to $1 \mathrm{~cm}$ long, 100-140 $\mu \mathrm{m}$ in diameter, of up to ca. 200 rows of uniformly thickened cells (50-60 epidermal cells, 140-150 inner cells), stem surface straight to remotely angled, without slime papillae; dorsal epidermal cells in surface view irregularly oblong, ca. 13-18 $\times 7-10 \mu \mathrm{m}$, thick-walled, deep green, ventral epidermal cells shorter, subquadrate, inner stem cells narrowly rectangular, pale; stems in cross section ca. 15 cells wide, with numerous strongly and \pm evenly thick-walled outer cells (in 3-4 rows) with small lumina surrounding 15-20 thinner-walled and larger inner cells. Branches ventral-intercalary, arising at straight angles from ventral surface of stem. Leaves and underleaves lacking but leaves sometimes indicated by a large, hyaline cell protruding from stem surface, places of leaf insertion indicated by remote crenations of stem surface. Cuticle smooth. Oil bodies present in all green cells of male and female bracts and perianth, (1-)2-5 per cell, rounded to ellipsoid, finely papillose, Jungermannia-type; oil bodies
Fig. 2. Phycolepidozia indica. A, habit with gynoecia and androecia (scale: $1 \mathrm{~mm}$ ); B, stem in cross section (scale: $50 \mu \mathrm{m}$ ); C, dehisced capsule (scale: $0.5 \mathrm{~mm}$ ); $\mathbf{D}$, cells of middle of inner valve surface (scale: 50 $\mu \mathrm{m})$; $\mathbf{E}$, seta in cross section (scale: $50 \mu \mathrm{m}$ ); $\mathbf{F}$, cells of perianth mouth (scale: $50 \mu \mathrm{m}$ ); $\mathbf{G}$, stem epidermis cells in surface view (scale: $50 \mu \mathrm{m}$ ).
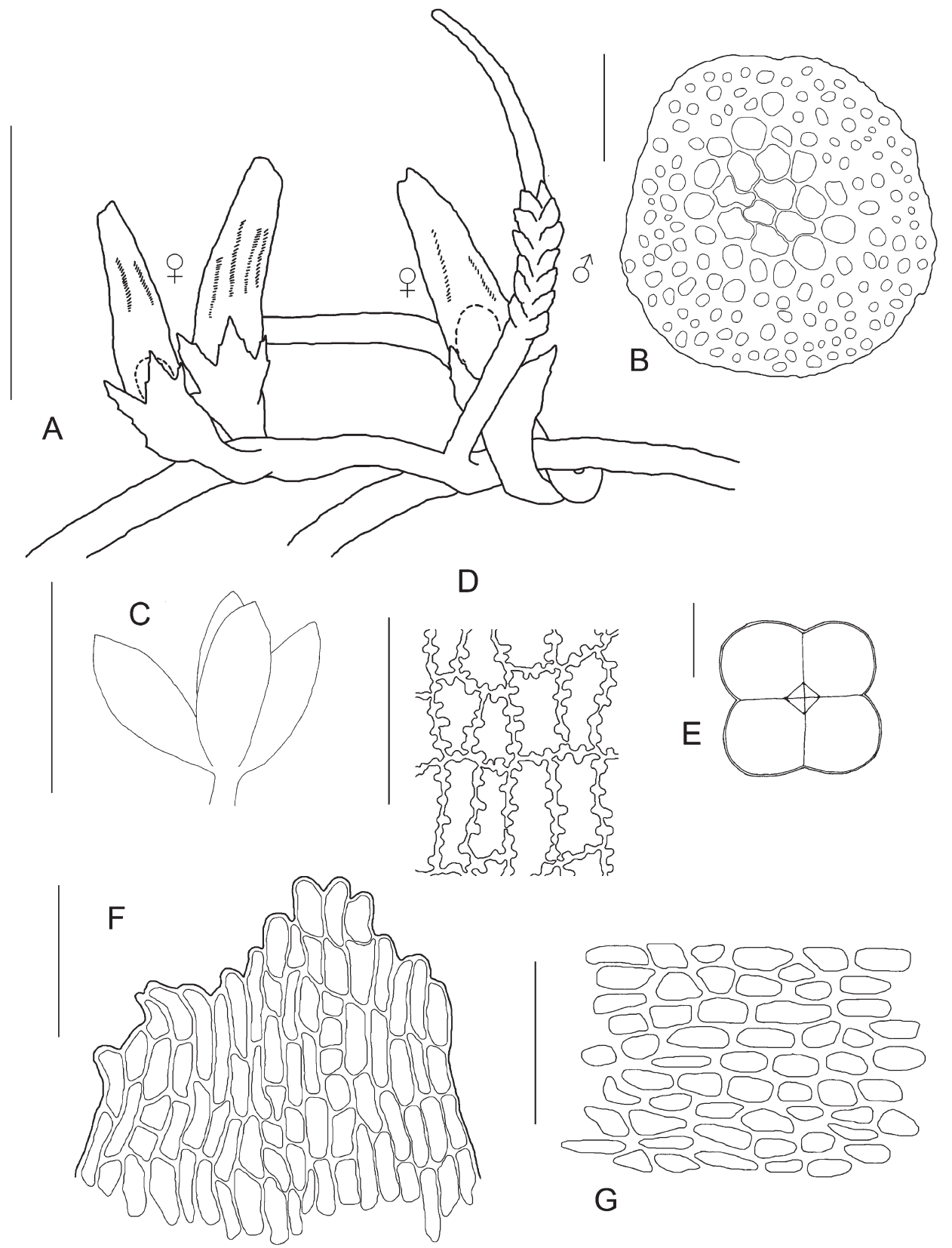

G 
apparently lacking in stem cells. Rhizoids hyaline to pale brown, very scarce, present on rhizomes and occasionally 1-2 near shoot tips, arising singly from ventral epidermal cells (not in bundles), on rhizomes dense and short, hyaline to pale brown, at shoot tips hyaline, elongate. Asexual reproduction not observed. Androecia terminal to intercalary (by continued growth of shoots) on main stems and short or long branches, spicate, leafy. Male bracts very small, imbricate, obliquely spreading, upper part and margins colorless, lower part green, in 6-10 pairs, $0.2 \times 0.15 \mathrm{~mm}$, bracts becoming smaller towards apex of spike, bifid to $1 / 3$, sinus wide, V-shaped, lobes triangular, ca. 6 cells long and 6 cells wide at base, bluntly acute, undivided part of lamina deeply pouched, made up of numerous non-tiered cells with evenly thickened walls, margins subentire, bases cuneate and acutely subauriculate; bracts with one globose antheridium; antheridial stalk not seen. Male bracteoles lacking. Gynoecia colorless, on short ventral branches, with connate bracts and bracteoles. Female bracts in 2-3 series, inner bract ovate-elongate, $0.3-0.4 \mathrm{~mm}$ long, appressed to perianth base below, spreading above, asymmetrically bifid (to max. 1/4), lobes subacute to shortly ciliate by 1-3 elongate cells, lobe margins irregularly crenate and sometimes with a large lobe-like tooth. Female bracteoles slightly shorter and narrower than bracts, more deeply bifid (to $1 / 3$ ), lobe margins subentire. Cells of bracts and bracteoles with evenly thickened walls. Perianth long-cylindrical, $1-1.3 \mathrm{~mm}$ long, deeply 3-keeled, upper part colorless, deeply 3-lobed at mouth (to 1/4 of perianth length), apical margin crenate.

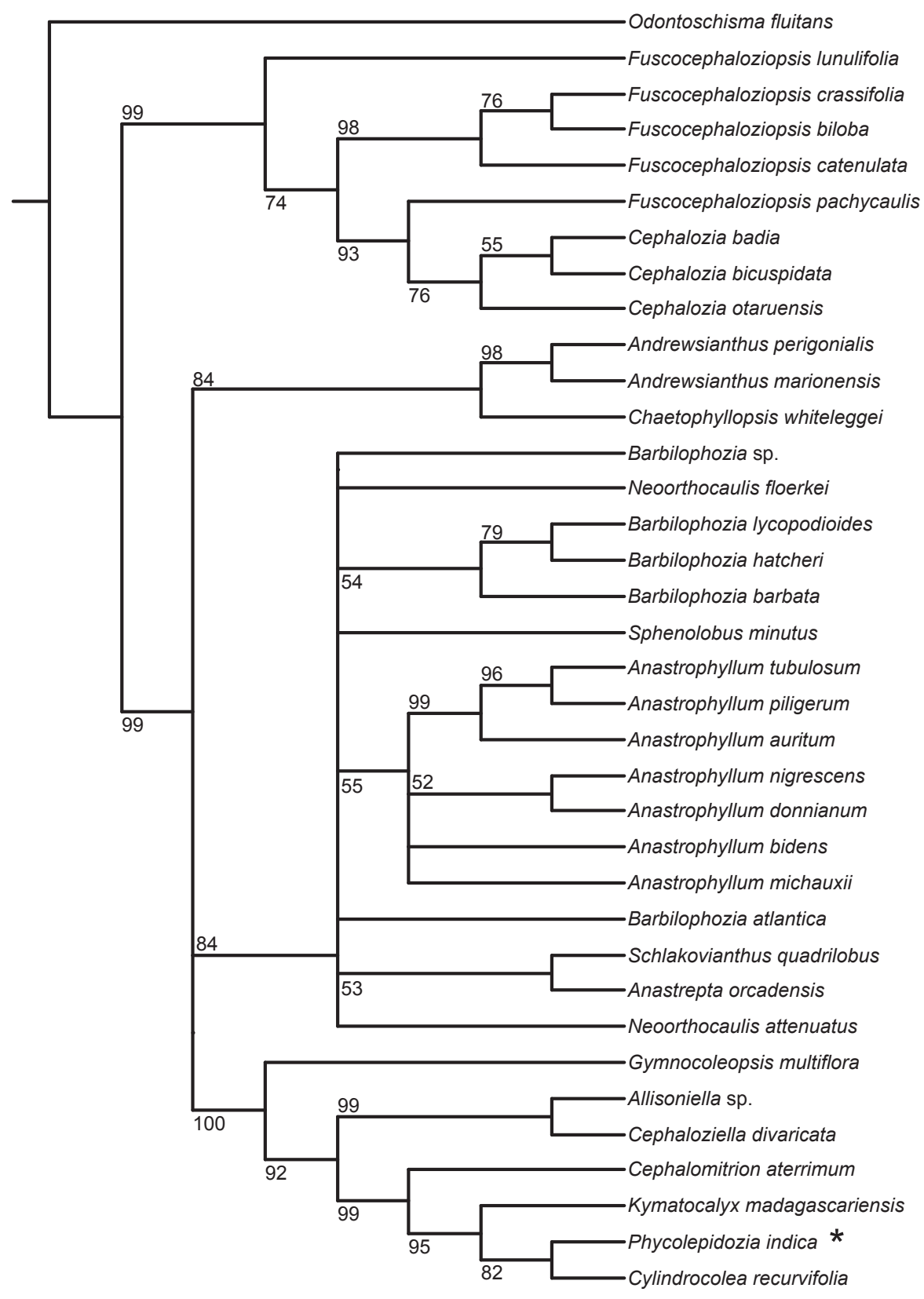

Fig. 3. Fifty percent majorityrule consensus tree based on 36 accessions using four cpDNA loci and showing the relationship among Cephaloziaceae, Scapaniaceae and Cephaloziellaceae. The position of Phycolepidozia is marked by an asterisk. Values on branches represent bootstrap support. 
Sporophyte: Seta very thin, ca. 100-120 $\mu \mathrm{m}$ in diameter, ca. $3 \mathrm{~mm}$ long upon elongation, not articulate, formed of 4 rows of very large epidermal cells surrounding 4 minute rows of opposite inner cells, epidermis cells in surface view subrectangular, ca. $70 \mu \mathrm{m}$ long and $50 \mu \mathrm{m}$ wide, inner cells lacking towards base of seta. Capsule dark brown, ellipsoid, $0.35 \times 0.25 \mathrm{~mm}$, quadrifid to near base. Valves straight, oblong-fusiform, $c a$. $0.4 \mathrm{~mm}$ long and $0.15 \mathrm{~mm}$ wide, ca. 15 cells long from base to apex, very thin, bistratose, outer layer wider than inner layer, cells of the two layers not perfectly overlapping. Valve cells not tiered, narrowly rectangular, becoming shorter towards apex; inner valve cells with numerous well-defined, brown, I-shaped thickenings present on all longitudinal and transversal walls, thickening elongate-nodular in surface view, 6-10 on long walls, 1-4 on short walls, thickenings not more pronounced on alternate walls; outer valve cells with much weaker thickenings, visible as dark brown spots in the walls and not nodular-elongate. Spores pale brown, $11-13 \mu \mathrm{m}$ in diameter, surface densely and finely punctate, 1-celled at dispersal. Elaters free, rather sinuous, tapered to one side, $8-10 \mu \mathrm{m}$ wide and 180-220(-250) $\mu \mathrm{m}$ long, with 2 brownish spirals. locality.

Distribution and ecology. - Only known from the type

Further specimens. - INDIA. Western Ghats, Karnataka, Coorg Distr., Mt. Tandiandamol, 1610 m, on shaded rocks in remnant forest along the summit trail, 30 Mar 2013, U. Schwarz \& B. Ram S.n. (hb. Schwarz 10752); ibid., 22 Dec 2013, U. Schwarz \& S. Kumar s.n. (hb. Schwarz 12300, 12301).

Molecular phylogeny. - The concatenation of the four loci resulted in a matrix of 2217 base pairs including 490 polymorphic sites; 289 positions were parsimony-informative. Since the MP and ML topologies did not show any major conflict, only the ML 50\% majority-rule consensus tree is shown here (Fig. 3). The tree contained two major well-supported clades, one including accessions of Cephaloziaceae (bootstrap support, BS 99) and the other accessions of Cephaloziellaceae (including Phycolepidozia indica) and Scapaniaceae (BS 99). The latter clade comprised three main lineages in an unresolved relationship, one containing the species of Cephaloziellaceae and Phycolepidozia indica (BS 100) and the two other ones the members of Scapaniaceae (both BS 84). Phycolepidozia indica was recovered in a strongly supported Cephaloziellaceae subclade (BS 99) together with Cephalomitrion aterrimum (Steph.) R.M.Schust., Cylindrocolea recurvifolia (Steph.) Inoue and Kymatocalyx madagascariensis (Steph.) Gradst. \& Váňa, being sister to Cylindrocolea recurvifolia with good support (BS 82).

\section{DISCUSSION}

Morphological differentiation of Phycolepidozia indica. - Phycolepidozia indica resembles P. exigua by having naked stems without leaves and underleaves and with leafy gametoecia, purely ventral-intercalary branching, scattered rhizoids, Jungermannia-type oil bodies, absence of trigones (cell walls thin or evenly thickened), small androecia intercalary on the stem with bifid bracts and no bracteoles, tristichous gynoecia on short-ventral branches with connate bracts and bracteoles, long-cylindrical and deeply 3-keeled perianths with a deeply lobed mouth, a thin seta made up of four large, non-tiered rows of outer cells and four minute inner rows, bistratose capsule valves with thickenings on all longitudinal walls, etc. (Fig. 2). In spite of these striking similarities, the two species differ morphologically in several important respects (Table 1; differences are italicized in the description). The most conspicuous difference is the massive stem of $P$. indica, which in cross section is made up of about 200 cells including numerous strongly thick-walled cells in 3-4 rows surrounding 15-20 larger and thinner-walled inner cells (Fig. 2B). In contrast, the stems of $P$. exigua are very thin, consisting of 6 rows (5 outer, 1 inner) of very thin-walled cells. Also, the epidermis cells in $P$. indica (Fig. 2G) are much smaller and much more thick-walled than those of $P$. exigua. Oil bodies are present and finely papillose in both species but in $P$. exigua they occur in stem cells (also

Table 1. Comparison of Phycolepidozia exigua R.M.Schust. and $P$. indica Gradst. \& al.

\begin{tabular}{lll}
\hline & Phycolepidozia exigua & Phycolepidozia indica \\
\hline Stems & $50 \mu \mathrm{m}$ in diam., of 6 rows of cells & $100-140 \mu \mathrm{m}$ in diam., of ca. 200 rows of cells \\
Leaf position & indicated by slime papillae & indicated by crenations on stem surface \\
Oil bodies & in stem cells (and in gametoecia?) & in gametoecia, not in stem cells \\
Male bracts & $3-6$ pairs & $6-10$ pairs \\
Male bract lobes & $2-3$ cells wide & $5-6$ cells wide \\
Male bract disc & $5-6$ cells in 1-2 tiers & numerous non-tiered cells \\
Perianth & $0.4-0.5$ mm long, 6-lobed, mouth longly ciliate & $1-1.3$ mm long, 3-lobed, mouth crenate \\
Capsule valves & $230 \mu \mathrm{m}$ long, of 4 rows of tiered cells & $400 \mu \mathrm{m}$ long, of 15 rows of non-tiered cells \\
Valve thickenings & on longitudinal walls only & on longitudinal and transverse walls \\
Spores & $13-15 \mu \mathrm{m}$ & $11-13 \mu \mathrm{m}$ \\
Elaters & $135-150 \mu \mathrm{m}$ long & $180-250 \mu \mathrm{m}$ long \\
Distribution & tropical America & India \\
Habitat & bark and soil & rock
\end{tabular}


in gametoecia?) whereas in $P$. indica they were observed in the gametoecia but not in stem cells.

Further differences are seen in the gametoecia and capsules of the two species (Table 1); many of these are quantitative, however. Thus, the male spikes of $P$. indica are longer than those of $P$. exigua and the male bracts are larger and made up of non-tiered cells (cells tiered in P. exigua). The perianths of $P$. indica are almost twice as long as in $P$. exigua and the mouth is 3-lobed and crenate, not 6-lobed and long-ciliate as in $P$. exigua. Furthermore, the capsules of $P$. indica are larger with valves almost twice as long as in $P$. exigua, the elaters somewhat longer and the spores slightly smaller than in P. exigua. A marked difference is seen in the capsule epidermis which is made up of about 15 rows of non-tiered cells in $P$. indica, with nodular thickenings occurring on both longitudinal and transverse valve walls (Fig. 2D). In P. exigua, the capsule epidermis is made up of only four rows of tiered cells and nodular thickenings are present only on longitudinal walls, not on transverse walls. It should be noted, however, that these characters are not always stable in leafy liverworts and may vary within species. In Cladopodiella franscisci (Hook.) Jörg. (Cephaloziaceae) and several species of Cephaloziella (Spruce) Schiffn. (Cephaloziellaceae), for example, thickenings may be present or absent on the transverse walls of the capsule epidermis, and in Cephaloziella spinigera R.M.Schust. the epidermal cells may be tiered or non-tiered within a single capsule (Schuster, 1974, 1980). These data suggest that the taxonomic importance of the differences in the capsule walls of the two Phycolepidozia species should not be overrated.

Nevertheless, the differences observed between $P$. exigua and $P$. indica, especially those in the stem and perianth mouth, indicate that the two species are morphologically rather distant to each other, and they are here therefore placed in different subgenera (see Taxonomic implications). It might even be argued that the two species are not congeneric and that $P$. indica should be given generic status. We refrain from placing $P$. indica in a separate genus, however. As shown by Vanderpoorten \& al. (2012) and others, an increasingly large number of monospecific genera of liverworts, among them several highly specialized and morphologically well-defined taxa, have recently been relegated to synonymy based on molecular evidence. Without molecular study of $P$. exigua, the creation of a monospecific genus for $P$. indica would seem to be premature. Genera are convenient taxonomic vehicles for the naming of groups of species (Humphries \& Linder, 2009); only in rare cases they represent single species. Given the current trend in liverwort systematics of reducing monospecific genera, we believe that description of new ones should be done with great care and be avoided unless the relationship of the respective taxon to other genera is clear. In case of $P$. exigua and $P$. indica, the latter principle does not apply. The morphological differences between the two species are considerable, however, and undoubtedly warrant placement of the two in separate subgenera.

Although vegetative leaves and underleaves are absent in $P$. indica, the position of the leaves on the stems seems to be indicated by remote crenations of the stem surface. Leaf position, whether incubous or succubous, could not be determined, however. Occasionally, a relatively large, hyaline cell is present on the crenation and this might possibly represent a rudimentary leaf. An ontogenetic study of the development of the gametophyte in this species is necessary to verify this assumption. Schuster (1966) described the presence of small, 2-celled papillae on the stem surface of $P$. exigua and tentatively interpreted these as rudimentary leaves. In $P$. indica, however, hyaline papillae were not observed.

Phylogeny of Phycolepidozia. - The results of the molecular analysis unequivocally show that $P$. indica is a member of the family Cephaloziellaceae. Consequently, Phycolepidozia and Phycolepidoziaceae are transferred to Cephaloziellaceae. Morphologically, the position of Phycolepidoziaceae in Cephaloziellaceae is strongly supported by the structure of the sporophyte, which is essentially similar in the two families and fundamentally different from that of Cephaloziaceae and Lepidoziaceae, with which Phycolepidoziaceae were also compared previously (Schuster, 1966; Gradstein \& al., 2001). Typical cephalozielloid features of the sporophyte of both $P$. exigua and $P$. indica are the highly reduced seta, consisting of four rows of large epidermis cells surrounding four rows of minute inner cells, and the bistratose capsule wall with thickenings on all longitudinal walls of the epidermal cells. The $4+4$ seta is unique to Cephaloziellaceae and not found in any other group of liverworts (e.g., Douin, 1914; Schuster, 1971; Crandall-Stotler \& al., 2009). Bistratose capsule walls are also found in Cephaloziaceae and Lepidoziaceae but in these two families thickenings are only developed on alternate walls of the epidermis ("two-phase development" of wall thickenings; Schuster, 1984). Scapaniaceae, which is part of the same clade Cephaloziellaceae in the molecular analysis (Fig. 3), shares with the latter family the presence of thickenings on all longitudinal epidermal walls but differs fundamentally by the thicker seta and capsule wall. Thus, the cephalozielloid sporophytes of $P$. exigua and $P$. indica clearly support their position in Cephaloziellaceae and refute placement of $P$. exigua in a separate family Phycolepidoziaceae as advocated by Schuster (1966), in spite of the leafless gametophyte. Further features supporting the placement of Phycolepidozia in Cephaloziellaceae are the Jungermannia-type oil bodies, the evenly thick-walled cells of stems and gametoecia, lacking trigones, as well as the scattered rhizoids. The similarities in the sporophytes and gametophytes of the two Phycolepidozia species suggests that their leafless habit has resulted from a single evolutionary event and is not due to convergence. A somewhat similar situation is seen in the moss genus Ephemeropsis K.I.Goebel.

The present molecular results confirm the monophyly of the Cephaloziellaceae. Based on molecular analyses, Forrest \& al. (2006), Heinrichs \& al. (2007), Hentschel \& al. (2007) and others (see also Crandall-Stotler \& al., 2009) found strong evidence for Cephaloziellaceae as a robust lineage sister to, but separate from, Scapaniaceae. De Roo \& al. (2007), however, resolved Cephaloziellaceae within a broadly defined Scapaniaceae, albeit with weak support. Our results show an unresolved relationship of the well-supported Cephaloziellaceae and two lineages of Scapaniaceae s.l. 
The deviating morphology of Phycolepidozia, viz. absence of leaves and underleaves in this "leafy" liverwort, indicates, along with an increasing body of evidence, that extreme morphological transformations can obscure the phylogenetic signal present in morphological data (e.g., Heinrichs \& al., 2012; Vanderpoorten \& al., 2012). This may sometimes lead to dramatic differences in the generic or even familial placement of taxa. Examples from liverworts include the monospecific genus Metzgeriopsis K.I.Goebel from Southeast Asia characterized by a unistratose thallus (often interpreted as an enlarged protonema) with leafy sexual branches arising from thallus margins. Recent molecular analysis showed that Metzgeriopsis is a highly modified member of the leafy liverwort genus Cololejeunea (Spruce) Schiffn. (Gradstein \& al., 2006). Similarly, the odd thalloid genus Mizutania Furuki \& Z.Iwats. resembling members of Aneuraceae but with leafy bracts, was recently shown to be a member of the leafy liverwort family Calypogeiaceae (Masuzaki \& al., 2010).

Among mosses several examples are known of genera with highly reduced gametophytes that were difficult to classify, for example Buxbaumia Hedw., Discelium Brid., Ephemerum Hampe, Ephemeropsis, Micromitrium Austin and Viridivellus I.G.Stone (Gradstein \& Wilson, 2008; Goffinet \& al., 2011). In all these groups, the gametophyte is largely replaced by a persistent, photosynthetically active protonema. A striking example is Ephemeropsis with E. trentepohlioides (Renner) Sainsbury in New Zealand and Tasmania and E. tjibodensis K.I.Goebel in Southeast Asia, North Australia and New Caledonia. Like Phycolepidozia, Ephemeropsis was long placed in a separate family, Ephemeropsidaceae (= Nemataceae), because of the highly modified gametophyte. The peristome and calyptra of Ephemeropsis, however, are similar to those of Daltoniaceae (Buck, 1988). Recent molecular analysis has confirmed that Ephemeropsis is a member of Daltoniaceae (Shaw \& al., 2003; Ho \& al., 2012). The latter study also showed that the two Ephemeropsis species form a monophyletic lineage, in spite of considerable morphological differences in the gametophyte and the sporophyte generation of the two (Bartlett \& Iwatsuki, 1985).

Examples of leafless taxa from vascular plants which were long difficult to classify are Cuscuta L. and Psilotum Sw. Cuscuta is a heterotrophic flowering plant with strongly reduced leaves, no roots and with reduced chloroplasts. Its leafless habit is similar to that of the heterotrophic Cassytha filiformis L. (Lauraceae) from Africa and is presumably an adaptation to its parasitic life style. Cuscuta has alternatively been treated as a member of Convolvulaceae or as a family in its own right, Cuscutaceae. The extreme reduction of morphological and anatomical characters of Cuscuta has made the systematic position of the genus uncertain. Molecular evidence has shown that the genus is a highly derived member of Convolulaceae (Neyland, 2001). Psilotum was traditionally placed in a separate phylum, Psilophyta, and considered by some the basalmost living vascular plant although relationships to the ophioglossoid ferns had also been noted. Molecular evidence has confirmed that Psilotum is a fern sister to Ophioglossales and not a separate phylum (Qiu \& Palmer, 1999; Pryer \& al., 2001).
There are several liverwort genera with highly unusual morphologies similar to those of Phycolepidozia, Metzgeriopsis and Mizutania that still need study. Examples are the Amazonian Amazoopsis J.J.Engel \& G.L.Merr. (Lepidoziaceae), Protocephalozia (Spruce) K.I.Goebel (Cephaloziaceae) and Pteropsiella Spruce (Lepidoziaceae), and Meinungeria Frank Müll. (Lepidoziaceae) from New Caledonia, all of which are characterized by the presence of leafy gametoecia and reduction of vegetative leaves and underleaves. Of these, Meinungeria superficially resembles Phycolepidozia by its worm-like, almost leafless stems and large, subsessile gynoecia (Müller, 2007: fig. 5). However, the presence in Meinungeria of vestigial underleaves (made up of 3-4 radially arranged single cells) and rhizoids originating in bundles from underleaf bases sharply separate this genus from Phycolepidozia. Sporophytes and androecia of Meinungeria are unknown. Owing to their unusual morphology, the phylogenetic relationships of Amazoopsis, Meinungeria, Protocephalozia and Pteropsiella remain unclear. Molecular phylogenetic work is necessary to determine the relationships of these unusual plants.

Distribution and ecology of Phycolepidozia indica. - Phycolepidozia indica was collected near the peak of Mt. Tandiandamol in the Western Ghats, South India. Mount Tandiandamol $(1750 \mathrm{~m})$ is the highest peak of the mountainous Coorg District, in the southern part of the Western Ghats. The district has a seasonal tropical climate with the monsoon season starting in June and lasting until November. Annual rainfall in the adjacent Madikeri district is up to $3500 \mathrm{~mm}$ with an average number of 118 rainy days per year (Pascal, 1982). Fog during morning hours in the cooler months also contributes to the precipitation. Temperatures range between $19^{\circ} \mathrm{C}$ and $23^{\circ} \mathrm{C}$ throughout the year. Geologically the area between Madikeri and Virajpet is made up of metamorphic crystalline rock (granitic gneiss). Suitable rock habitats for bryophytes are mountain cliffs, river banks and sides of tracks. The forest of the summit area of Mt. Tadiandamol is dense and evergreen and has been classified as Schefflera-Gordonia obtusa-Meliosma forest (Pascal, 1986). The predominant tree species are Cinnamomum verum, Gordonia obtusa, Litsea stocksii, Meliosma simplicifolia subsp. pungens, Neolitsea zeylanica, Phoebe wighti, Schefflera micrantha, Syzygium caryophyllatum and S. hemisphericum.

Bryological exploration of the Western Ghats has a long history, dating back to the 19th century, and the area is being considered a hotspot of biodiversity (Gunawardene \& al., 2007). Nevertheless, most bryophyte collecting has been done in parts of the Ghats further to the south, belonging to the states of Kerala and Tamil Nadu. Locations such as the Nilghiri Mts., Palni Hills and Kodaikanal are famous for their richness in species and are the type localities for many species of bryophytes (Manju \& al., 2008; Daniels, 2010). In contrast, the adjacent parts of the Western Ghats belonging to the state of Karnataka remain largely unexplored (Frahm \& al., 2013). Mount Tandiandamol was visited by L.T. Walker in 1897-98, who collected only moss species (see list in Brotherus, 1899). Records of liverworts from the area are few (Alam, 2012; Verma, 2009), but a comprehensive checklist of liverworts of the Coorg District does not exist. 
Currently, the mountain slopes of Mt. Tandiandamol are heavily deforested and the natural vegetation is largely replaced by coffee plantations up to $1200 \mathrm{~m}$ and by open grassland with bushes between 1200-1750 m. Some small patches of forest remain in ravines and along the summit trail at $1600-1700 \mathrm{~m}$. Phycolepidozia indica was found on metamorphic crystalline rock in remnant forest along the summit trail, and was quite conspicuous in the field by its naked, leafless stems with numerous gametoecia (Fig. 1). Associated bryophyte species were the mosses Fissidens sp., Dixonia orientalis (Mitt.) H.Akiy. \& Tsubota and Thamniopsis utacamundiana (Mont.) W.R.Buck; no other liverwort species were seen growing associated with $P$. indica. Upon its discovery in November 2012 the species was found on a single rock, but during a revisit of the type locality in December 2013 the species was seen on six further rocks within the forest patch. Possibly, the species has been widespread in the area in the past but has become scarce following deforestation of the slopes of Mt. Tandiandamol.

Biogeography of Phycolepidozia. - The disjunct occurrence of Phycolepidozia in the Neotropics and in southern India is intriguing. Thorne (1972) referred to these tropical Asian-Neotropics ranges as amphi-Pacific tropical disjunctions and enumerated 89 genera of flowering plants exhibiting this type of distribution. Past migration via the North Atlantic bridges followed by local extinction and long-range dispersal have been used most commonly to explain these amphiPacific disjunctions, but only few examples have been analysed with molecular phylogenetic and biogeographic methods ( $\mathrm{Li}$ \& Wen, 2013).

Among bryophytes, amphi-Pacific tropical disjunctions occur in 16 genera, 7 of mosses and 9 of liverworts (Table 2). The list does not claim to be exhaustive and more bryophyte taxa exhibiting this type of distribution may exist. The amphiPacific tropical disjuncts occur in different habitats such as on tree trunks (Elmerobryum, Mniomalia, Sorapilla, Pictolejeunea, Spruceanthus, Vitalianthus), rock (Cololejeunea subg. Chlorolejeunea, Ganguleea, Hymenostyliella, Luisierella, Myriocoleopsis), rotten logs or soil (Lobatiriccardia), living leaves (Cololejeunea subg. Chlorolejeunea, Drepanolejeunea subg. Rhaphidolejeunea) and on twigs and branches in the outer canopy of the rainforest (Ceratolejeunea grandiloba, Rectolejeunea). Dispersal scenarios rather than geographical vicariance have usually been proposed by recent authors as the preferred explanations for the intercontinental ranges of bryophyte species and genera (Heinrichs \& al., 2009; Gradstein, 2013b). However, most of the amphi-Pacific tropical disjuncts with the exception of Cololejeunea subg. Chlorolejeunea, Myriocoleopsis, Lobatiriccardia and Vitalianthus have not been analysed by molecular phylogenetic methods, and their taxonomic circumscriptions are largely based on morphology.

To better understand their biogeographic histories, the taxonomic status and distribution of these disjuncts need to be analysed by robust methods. For example, phylogenetic analysis of the putatively Asian-Neotropical Echinocolea R.M.Schust.

Table 2. Amphi-Pacific tropical disjunctions in bryophytes.

\begin{tabular}{|c|c|c|c|}
\hline Taxon & $\begin{array}{l}\text { No. of } \\
\text { species }\end{array}$ & Distribution & Reference \\
\hline \multicolumn{4}{|l|}{ Mosses } \\
\hline Austinia Müll.Hall. & 2 & SE Asia, Neotropics & Buck \& Crum, 1978; Gradstein \& al., 2001 \\
\hline Elmeriobryum Broth. & 3 & SE Asia, C America & Buck \& Tan, 2007 \\
\hline Ganguleea R.H.Zander & 1 & Himalayas, SE Brazil & Zander, 1993 \\
\hline Hymenostyliella Bartr. & 3 & SE Asia, Brazil & Zander, 1993 \\
\hline Luisierella Thér. \& P.Varde & 1 & Japan, Java, Neotropics & Zander, 1993 \\
\hline Mniomalia Müll.Hal. & 2 & SE Asia, Neotropics & Norris \& Koponen, 1987 \\
\hline Sorapilla Mitt. \& Spruce & 2 & E Malesia, N Australia, Ecuador & Norris \& Koponen, 1987 \\
\hline \multicolumn{4}{|l|}{ Liverworts } \\
\hline Ceratolejeunea grandiloba J.B.Jack \& Steph. & 1 (2 subsp.) & Java, tropical Andes & Gradstein, 2013a \\
\hline Cololejeunea subg. Chlorolejeunea Benedix & 2 & SE Asia, Ecuador & Gradstein \& al., 2011 \\
\hline $\begin{array}{l}\text { Drepanolejeunea subg. Rhaphidolejeunea } \\
\text { (Herzog) Grolle \& R.L.Zhu }\end{array}$ & 11 & SE Asia, Amazonia & Grolle \& Zhu, 2000 \\
\hline Lobatiriccardia (Mizut. \& S.Hatt.) Furuki & 8 & SE Asia, Australasia, Ecuador & Preußing \& al., 2010; Nebel \& al., 2013 \\
\hline Myriocoleopsis Schiffn. & 3 & Vietnam, SE Brazil, Ecuador & Pócs, 2010 \\
\hline Phycolepidozia R.M.Schust. & 2 & India, Neotropics & this paper \\
\hline Pictolejeunea Grolle & 6 & Borneo, Neotropics & Grolle, 1977; Pócs, 2007 \\
\hline Rectolejeunea A.Evans & 5 & N Australia, Neotropics & Reiner-Drehwald \& Grolle, 2012 \\
\hline Spruceanthus Verd. & 9 & SE Asia, Australia, Ecuador, Europe $(\dagger)$ & Grolle, 1985; Gradstein \& al., 2001, 2002 \\
\hline Vitalianthus R.M.Schust. \& Giancotti & 2 & China, Brazil & Wei \& al., 2013 \\
\hline
\end{tabular}


showed that the genus is nested in Lejeunea Lib. and may not be monophyletic (Ilkiu-Borges, 2005; but see Heinrichs \& al., 2013). Similarly, the circumscriptions of the amphi-Pacific genera Myriocoleopsis, Spruceanthus and Vitalianthus have become questionable based on recent molecular studies (Wilson \& al., 2007; Yu \& al., 2013; R.L. Zhu, pers. com.). On the other hand, it should be taken into account that the disjunct amphiPacific ranges may reflect insufficient collecting. The moss genus Campylopodiella Card., for example, was long known only from the Neotropics and the Himalayan region and considered an amphi-Pacific disjunct, but was recently detected in Africa (Townsend, 2009). Undercollecting is likely in the case of Phycolepidozia due to its minute size. It may also hold for the epiphyllous Drepanolejeunea subg. Rhaphidolejeunea, the rheophytic Cololejeunea subg. Chlorolejeunea and Myriocoleopsis, and the canopy specialists Ceratolejeunea grandiloba and Rectolejeunea, all of which grow in habitats that have been little inventoried. More intensive exploration of their habitats may reveal additional localities for these intriguing amphiPacific taxa.

\section{Taxonomic implications}

Cephaloziellaceae Douin in Mém. Soc. Bot. France 29: 1.1920 - Type: Cephaloziella (Spruce) Schiffn.

$=$ Phycolepidoziaceae R.M.Schust. in Bull. Torrey Bot. Club 93: 442. 1966, syn. nov. - Type: Phycolepidozia R.M.Schust.

Phycolepidozia R.M.Schust. in Bull. Torrey Bot. Club 93: 438. 1966 - Type: P. exigua R.M. Schust.

Contains two species, in 2 subgenera.

\section{Phycolepidozia subg. Phycolepidozia}

Stem of 6 rows of cells. Male bract disc of 5-6 cells in 1-2 tiers. Perianth mouth 6-lobed, longly ciliate. Capsule valves ca. $230 \mu \mathrm{m}$ long, of 4 rows of tiered cells; thickening present on longitudinal walls only.

Contains P. exigua R.M.Schust. from Dominica and Venezuela.

Phycolepidozia subg. Metaphycolepidozia Gradst., J.-P.Frahm \& U.Schwarz, subg. nov. - Type: P. indica Gradst., J.-P. Frahm \& U.Schwarz

Stem of ca. 200 rows of cells. Male bract disc of numerous non-tiered cells. Perianth mouth 3-lobed, crenate. Capsule valves ca. $400 \mu \mathrm{m}$ long, of 15 rows of non-tiered cells; thickenings present on longitudinal and transverse walls.

Contains $P$. indica Gradst. \& al. from South India.

\section{ACKNOWLEDGEMENTS}

We are grateful to the editor-in-chief of Taxon and two anonymous reviewers for constructive comments and corrections on the manuscript. The work of Benjamin Laenen was supported by a BelPDcofund Marie Curie fellowship of the European Commission.

\section{口 LITERATURE CITED}

Alam, A. 2012. Liverwort flora of Parson's valley, Nilgiri hills (Western Ghats), South India. Arch. Bryol. 119: 1-20.

Bartlett, J.K. \& Iwatsuki, Z. 1985. The bryophyte flora of New Zealand-Taxonomy and distribution of Ephemeropsis trentepohliodes and E. tjibodensis with a note on the ecology and distribution of Buxbaumia novae-zelandia. New Zealand J. Bot. 23: 179-182. http://dx.doi.org/10.1080/0028825X.1985.10425322

Brotherus, V.F. 1899. Report on a collection of mosses made by Dr. T.L. Walker in Coorg during the cold weather of 1897-98. Rec. Bot. Surv. India 1: 311-329.

Buck, W.R. 1988. Another view of familial delimitation in the Hookeriales. J. Hattori Bot. Lab. 64: 29-36.

Buck, W.R. \& Crum, H. 1978. A re-interpretation of the Fabroniaceae with notes on selected genera. J. Hattori Bot. Lab. 44: 347-369.

Buck, W.R. \& Tan, B.C. 2007. A review of Elmeriobryum (Hypnaceae). Telopea 12: 251-256.

Crandall-Stotler, B., Stotler, R. \& Long, D. 2009. Phylogeny and classification of the Marchantiophyta. Edinburgh J. Bot. 66: 155-198. http://dx.doi.org/10.1017/S0960428609005393

Daniels, A.E.D. 2010. Checklist of the bryophytes of Tamil Nadu, India. Arch. Bryol. 65: 1-117.

De Roo, R.T., Hedderson, T.A. \& Söderström, L. 2007. Molecular insights into the phylogeny of the leafy liverwort family Lophoziaceae. Taxon 56: 301-314.

Douin, C. 1914. Le sporogone des Céphaloziellacées. Rev. Gén. Bot. 25: 179-195.

Forrest, L.L., Davis, E.C., Long, D.G., Crandall-Stotler, B.J., Clark, A. \& Hollingsworth, M.L. 2006. Unraveling the evolutionary history of the liverworts (Marchantiophyta)-Multiple taxa, genomes, and analyses. Bryologist 109: 303-334. http://dx.doi.org/10.1639/0007-2745(2006)109[303:UTEHOT]2.0 $\mathrm{CO} ; 2$

Frahm, J.-P., Schwarz, U. \& Manju, C.N. 2013. A checklist of the mosses of Karnataka, India. Arch. Bryol. 158: 1-15.

Fulford, M.H. 1968. Phycolepidoziaceae. Manual of the leafy Hepaticae of Latin America, Part III. Mem. New York Bot. Gard. 11: 382-384.

Goffinet, B., Budke, J.M. \& Newman, L.C. 2011. Micromitriaceae: A new family of highly reduced mosses. Taxon 60: 1245-1254.

Gouy, M., Guindon, S. \& Gascuel, O. 2010. SeaView Version 4: A multiplatform graphical user interface for sequence alignment and phylogenetic tree building. Molec. Biol. Evol. 27: 221-224. http://dx.doi.org/10.1093/molbev/msp259

Gradstein, S.R. 2013a. Notes on early land plants today 26. Miscellaneous new synonyms in liverworts. Phytotaxa 81: 3-7. http://dx.doi.org/10.11646/phytotaxa.81.1.2

Gradstein S.R. 2013b. Afro-Amerıcan hepatics revisited. Polish Bot. J. 58: 149-177.

Gradstein, S.R. \& Wilson, R. 2008. Protonemal neoteny in bryophytes. Pp. 1-11 in: Mohamed, H., Bakar, B.B., Boyce, A.N. \& Lee, P.K.Y. (eds.), Bryology in the new millenium. Kuala Lumpur: University of Malaya.

Gradstein, S.R., Churchill, S.P. \& Salazar Allen, N. 2001. Guide to the bryophytes of tropical America. Mem. New York Bot. Gard. 86: $1-577$.

Gradstein, S.R., He, X.-L., Piippo, S. \& Mizutani, M. 2002. Bryophyte flora of the Huon Peninsula, Papua New Guinea LXVIII. Lejeuneaceae subfamily Ptychanthoideae (Hepaticae). Acta Bot. Fenn. 174: 1-88.

Gradstein, S.R., Wilson, R., Ilkiu-Borges, A.L. \& Heinrichs, J. 2006. Phylogenetic relationships and neotentic evolution of Metzgeriopsis (Lejeuneaceae) based on chloroplast DNA sequences and morphology. Bot. J. Linn. Soc. 151: 293-308. http://dx.doi.org/10.1111/].1095-8339.2006.00531.x

Gradstein, S.R., Ilkiu-Borges, A.-L. \& Vanderpoorten, A. 2011. Habitat specialization triggers the evolution of unusual morphologies: 
The case of Cololejeunea stotleriana sp. nov. from Ecuador. Bryologist 114: 9-22.

http://dx.doi.org/10.1639/0007-2745-114.1.9

Grolle, R. 1977. Pictolejeunea-eine neue Gattung der Lejeuneoideae aus der Neotropis und Borneo. Feddes Repert. 88: 247-256. http://dx.doi.org/10.1002/fedr.19770880402

Grolle, R. 1985. Fossil Spruceanthus in Europe and two other hepatics in Baltic amber. Prace Muz. Ziemi 37: 79-85.

Grolle, R. \& Zhu, R.-L. 2000. A study of Drepanolejeunea subg. Rhaphidolejeunea (Herzog) Grolle \& R.L. Zhu, stat. nov. (Hepaticae, Lejeuneaceae) in China with notes on its species elsewhere. Nova Hedwigia 70: 373-396.

Gunawardene, N.R., Dulip Daniels, A.E., Gunatilleke, I.A.U.N., Gunatilleke, C.V.S., Karunakaran, P.V., Geetha Nayak, K., Prasad, S., Puyravaud, P., Ramesh, B.R., Subramanian, K.A. \& Vasanthy, G. 2007. A brief overview of the Western Ghats-Sri Lanka biodiversity hotspot. Curr. Sci. 93: 1567-1572.

Hallingbäck, T. 2013. Phycolepidozia exigua. In: IUCN Red List of Threatened Species. Version 2013.1. http://www.iucnredlist.org (accessed 1 Sep 2013).

Heinrichs, J., Hentschel, J., Wilson, R., Feldberg, K. \& Schneider, H. 2007. Evolution of leafy liverworts (Jungermanniidae, Marchantiophyta): Estimating divergence times from chloroplast DNA sequences using penalized likelihood with integrated fossil evidence. Taxon 56: 31-44.

Heinrichs, J., Hentschel, J., Feldberg, K., Bombosch, A. \& Schneider, H. 2009. Phylogenetic biogeography and taxonomy of disjunctly distributed bryophytes. J. Syst. Evol. 47: 497-508. http://dx.doi.org/10.1111/j.1759-6831.2009.00028.x

Heinrichs, J., Dong, S., Yu, Y., Schäfer-Verwimp, A., Pócs, T., Feldberg, K., Hentschel, J., Schmidt, A. \& Schneider, H. 2012. A 150year mystery solved: Transfer of the rheophytic endemic liverwort Myriocolea irrorata to Colura. Phytotaxa 66: 55-64.

Heinrichs, J., Dong, S., Schäfer-Verwimp, A., Pócs, T., Feldberg, K., Czumaj, A., Schmidt, A.R., Reitner, J., Renner, M.A.M., Hentschel, J., Stech, M. \& Schneider, H. 2013. Molecular phylogeny of the leafy liverwort Lejeunea (Porellales): Evidence for a neotropical origin, uneven distribution of sexual systems and insufficient taxonomy. PloS ONE 8: e82547.

http://dx.doi.org/10.1371/journal.pone.0082547

Hentschel, J., Paton, J.A., Schneider, H. \& Heinrichs, J. 2007. Acceptance of Liochlaena Nees and Solenostoma Mitt., the systematic position of Eremonotus Pearson and notes on Jungermannia L. s.l. (Jungermanniidae) based on chloroplast DNA sequence data. $P l$. Syst. Evol. 268: 147-157. http://dx.doi.org/10.1007/s00606-007-0549-7

Ho, B.-C., Pokorny, L., Tan, B., Frahm, J.-P., Shaw, A.J. \& Quandt, D. 2012. Molecular evolution and diversification of the moss family Daltoniaceae (Hookeriales, Bryophyta) with emphasis on unraveling the phylogeny of Distichophyllum and its allies. Bot. J. Linn. Soc. 170: 157-175. http://dx.doi.org/10.1111/j.1095-8339.2012.01279.x

Humphries, A.M. \& Linder, H.P. 2009. Concept versus data in delimitation of plant genera. Taxon 58: 1054-1074.

Ilkiu-Borges, A.L. 2005. A taxonomic revision of Echinocolea (Lejeuneaceae, Hepaticae). Nova Hedwigia 80: 45-71. http://dx.doi.org/10.1127/0029-5035/2005/0080-0045

Laenen, B., Désamoré, A., Devos, N., Shaw, A.J., González-Mancebo, J.M., Carine, M.A. \& Vanderpoorten, A. 2011. Macaronesia: a source of hidden genetic diversity for post-glacial recolonization of western Europe in the leafy liverwort Radula lindenbergiana. J. Biogeogr. 38: 631-639. http://dx.doi.org/10.1111/j.1365-2699.2010.02440.x

Li, R. \& Wen, J. 2013. Phylogeny and biogeography of Dendropanax (Araliaceae), an amphi-Pacific disjunct genus between tropical/ subtropical Asia and the Neotropics. Syst. Bot. 38: 536-551. http://dx.doi.org/10.1600/036364413X666606
Liu, K., Linder, C.R. \& Warnow, T. 2011. RAxML and FastTree: Comparing two methods for large-scale maximum likelihood phylogeny estimation. PLoS ONE 6: e27731.

http://dx.doi.org/10.1371/journal.pone.0027731

Manju, C.N., Rajesh, K.P. \& Madhusoodanan, P.V. 2008. Checklist of the bryophytes of Kerala, India. Trop. Bryol. Res. Rep. 7: 1-24.

Masuzaki, H., Shimamura, M., Furuki, T., Tsubota, H., Yamaguchi, T., Majid, H.M.A. \& Deguchi, H. 2010. Systematic position of the enigmatic liverwort Mizutania (Mizutaniaceae, Marchantiophyta) inferred from molecular phylogenetic analyses. Taxon 59: 448-58.

Miller, M.A., Holder, M.T., Vos, R., Midford, P.E., Liebowitz, T., Chan, L., Hoover, P. \& Warnow, T. 2009. The CIPRES Portals. http://www.phylo.org/sub

Müller, F. 2007. Meinungeria mouensis (Lepidoziaceae), a new genus and species from New Caledonia. Bryologist 110: 494-499. http://dx.doi.org/10.1639/0007-2745(2007)110[494:MMLANG]2.0 $\mathrm{CO} ; 2$

Nebel, M., Söderström, L., Hagborg, L. \& Konrat, M. von 2013. Notes on early land plants today 28 . Transfers of some taxa to Lobatiriccardia (Aneuraceae, Marchantiophyta). Phytotaxa 81: 10-11. http://dx.doi.org/10.11646/phytotaxa.81.1.4

Neyland, R. 2001. A phylogeny inferred from large ribosomal subunit (26S) rDNA sequences suggests that Cuscuta is a derived member of Convolvulaceae. Brittonia 53: 108-115. http://dx.doi.org/10.1007/BF02805402

Norris, D.H. \& Koponen, T. 1987. Bryophyte flora of the Huon Peninsula, Papua New Guinea. XX. Fissidentaceae, Mitteniaceae, Phyllodrepaniaceae, Phyllogoniaceae and Sorapillaceae. Ann. Bot. Fenn. 24: 177-219.

Pascal, J.P. 1982. Bioclimates of the Western Ghats. Pondicherry: Institute Français de Pondichéry.

Pascal, J.P. 1986. Explanatory booklet on the forest map of South India. Sheets: Belgaum-Dharwar-Panaji, Shimoga, Mercara-Mysore. Pondicherry: Institute Français de Pondichéry.

Pócs, T. 2007. A sixth species of Pictolejeunea (Jungermanniopsida) from the Venezuelan Guyana. Acta Bot. Hung. 40: 109-119. http://dx.doi.org/10.1556/ABot.49.2007.1-2.12

Pócs, T. 2010. Myriocoleopsis in Southeast Asia. Trop. Bryol. 31: 123-125.

Preußing, M., Olsson, S., Schäfer-Verwimp, A., Wickett, N.J., Wicke, S., Quandt, D. \& Nebel, M. 2010. New insights in the evolution of the liverwort family Aneuraceae (Metzgeriales, Marchantiophyta) with an emphasis on the genus Lobatiriccardia. Taxon 59: 1424-1440.

Pryer, K.M., Schneider, H., Smith, A.R., Cranfill, R., Wolf, P.G., Hunt, J.S. \& Sipes, S.D. 2001. Horsetails and ferns are a monophyletic group and the closest living relatives to seed plants. Nature 409: 618-621. http://dx.doi.org/10.1038/35054555

Qiu, Y.-L. \& Palmer, J. 1999. Phylogeny of early land plants: Insights from genes and genomes. Trends Pl. Sci. 4: 26-30. http://dx.doi.org/10.1016/S1360-1385(98)01361-2

Reiner-Drehwald, M.E \& Grolle, R. 2012. Review of the genus Rectolejeunea (Lejeuneaceae, Marchantiophyta). Nova Hedwigia 95: 451-482. http://dx.doi.org/10.1127/0029-5035/2012/0063

Schäfer-Verwimp, A. 2010. A checklist of the liverworts and hornworts of Dominica, West Indies. Cryptog. Bryol. 31: 313-415.

Schuster, R.M. 1966. Studies on Hepaticae XXVIII. On Phycolepido$z i a$, a new, highly reduced genus of Jungermanniales of questionable affinity. Bull. Torrey Bot. Club 93: 437-449. http://dx.doi.org/10.2307/2483417

Schuster, R.M. 1971. Studies on Cephaloziellaceae. Nova Hedwigia 22: $121-265$.

Schuster, R.M. 1974. The Hepaticae and Anthocerotae of North America East of the Hundredth Meridian, vol. 3. New York: Columbia University Press.

Schuster, R.M. 1980. The Hepaticae and Anthocerotae of North America East of the Hundredth Meridian, vol. 4. New York: Columbia University Press. 
Schuster, R.M. 1984. Comparative anatomy and morphology of the Hepaticae. Pp. 760-1070 in: Schuster, R.M. (ed.), New manual of bryology, vol. 2. Nichinan: The Hattori Botanical Laboratory.

Shaw, A.J., Cox, C.J., Goffinet, B., Buck, W.R. \& Boles, S.B. 2003. Phylogenetic evidence of a rapid radiation of pleurocarpous mosses (Bryophyta). Evolution 57: 2226-2241. http://dx.doi.org/10.1111/j.0014-3820.2003.tb00235.x

Sikes, D.S. \& Lewis, P.O. 2001. PAUPRat: PAUP implementation of the parsimony ratchet; beta software, version 1. Storrs: Department of Ecology and Evolutionary Biology, University of Connecticut.

Stech, M. \& Quandt, D. 2010. 2000 species and five key markers: The status of molecular bryophyte systematics. Phytotaxa 9: 196-228.

Thorne, R.F. 1972. Major disjunctions in the geographic ranges of seed plants. Quart. Rev. Biol. 47: 365-411. http://dx.doi.org/10.1086/407399

Townsend, C.C. 2009. Campylopodiella dorothyae sp. nov., a genus and species new to Africa. J. Bryol. 31: 127-129. http://dx.doi.org/10.1179/174328209X427515

Vanderpoorten, A., Désamoré, A., Laenen, B. \& Gradstein, S.R. 2012. Striking autapomorphic evolution in Physotheca J.J. Engel
\& Gradst. (Lophocoleaceae) blurred its actual relationships with Leptoscyphus Mitt. J. Bryol. 34: 251-256. http://dx.doi.org/10.1179/1743282012Y.0000000018

Verma, P.K. 2009. Genus Cololejeunea (Spruce) Schiffn. in Nilgiri Hills (Western Ghats). Nelumbo 51: 157-160.

Wei, Y.-M., He, Q., Gradstein, S.R., Campos, L.V. \& Zhu R.-L. 2013. Notes on early land plants today. 46. Transfer of Vitalianthus urubuensis (Marchantiophyta: Lejeuneaceae) to Cheilolejeunea. Phytotaxa 50: 50-52. http://dx.doi.org/10.11646/phytotaxa.152.1.5

Wilson, R., Gradstein, S. R., Schneider, H. \& Heinrichs, J. 2007. Unravelling the phylogeny of Lejeuneaceae (Jungermanniopsida): Evidence for four main lineages. Molec. Phylogen. Evol. 43: 270-282. http://dx.doi.org/10.1016/j.ympev.2006.10.017

Yu, Y., Pócs, T., Schäfer-Verwimp, A., Heinrichs, J., Zhu, R.-L. \& Schneider, H. 2013. Evidence for rampant homoplasy in the phylogeny of the epiphyllous liverwort genus Cololejeunea (Lejeuneaceae). Syst. Bot. 38: 553-563. http://dx.doi.org/10.1600/036364413X670304

Zander, R. 1993. Genera of the Pottiaceae. Bull. Buffalo Soc. Nat. Sci. 32: $1-378$.

Appendix 1. GenBank accession numbers ( $p b s A, p s b T, r b c L, r p s 4$ ) of species used in this study. LiToL number, provenance, collector(s), collection number and (herbarium) and are provided for sequences newly generated in this study.

CEPHALOZIACEAE. Cephalozia badia (Gottsche) Steph., KC184779.1,-, KC184710.1,-; Cephalozia bicuspidata (L.) Dumort., KC184781.1,-, AY462291, JF513486.1; Cephalozia otaruensis Steph., KC184781.1, -, AB476560.1, -; Fuscocephaloziopsis biloba (Herzog) Fulford, -, -, KC184712.1, -; Fuscocephaloziopsis catenulata (Huebener) Váňa \& L.Söderstr., -, -, -, AY608053.1; Fuscocephaloziopsis crassifolia (Lindenb. \& Gottsche) Váňa \& L.Söderstr., KC184780.1,-, KC184711.1, AM398309.1; Fuscocephaloziopsis lunulifolia (Dumort.) Váňa \& L.Söderstr., -, -, -, AM398315.1; Fuscocephaloziopsis pachycaulis (R.M.Schust.) Váňa \& L.Söderstr., KC184782.1, -, KC184714.1, -; Odontoschisma fluitans (Nees) L.Söderstr. \& Váňa, KC184789.1, -, JX305542.1, - . CEPHALOZIELLACEAE. Allisoniella sp., FATOL788, New Zealand, Engel \& Konrat 28608 (F), KF851891, -, -, KF851429; Cephalomitrion aterrimum (Steph.) R.M.Schust., L1226, New Zealand, Engel \& Konrat 28545 (F), KF851926, -, KF852368, KF851459; Cephaloziella divaricata (Sm.) Schiffn., L1426, Czech Republic, Sova s.n. (DUKE), KF851965, KF852248, KF852399, KF851489; Cylindrocolea recurvifolia (Steph.) Inoue, FATOL445, Japan, Yamaguchi s.n. 23 Sep 2007 (F), KF851848, KF852130, KF852297, KF851399; Gymnocoleopsis cylindriformis (Mitt.) R.M.Schust. (= G. multiflora (Steph.) R.M.Schust.), Venezuela, Söderström 2004/091 (BOL), -, -, -, AM398239; Kymatocalyx madagascariensis (Steph.) Gradst. \& Váňa, IBC64, Madagascar, Pocs 9446/AQ (F), AY607990, KF852200, -, AY608111; Phycolepidozia indica Gradst. \& al., S India, Schwarz 10659 (PC), KF862486, KF895402, KF862485, KF895403. SCAPANIACEAE. Anastrepta orcadensis (Hook.) Schiffn., JF513391.1, JF513407.1, JF513450.1, JF513468.1; Anastrophyllum auritum (Lehm.) Steph., KC184771.1, -, KC184702.1, -; Anastrophyllum bidens (Reinw. \& al.) Steph., KC184769.1, -, KC184700.1, -; Anastrophyllum donnianum (Hook.) Steph., KC184770.1, -, KC184701.1, -; Anastrophyllum michauxii (F.Weber) A.Evans, -, -, AY507390.1, AY507433.1; Anastrophyllum nigrescens (Mitt.) Steph., KC184772.1, -, KC184703.1, -; Anastrophyllum piligerum (Reinw. \& al.) Steph., KC184773.1,-, KC184704.1, -; Anastrophyllum tubulosum (Nees) Grolle, KC184774.1, -, KC184705.1, -; Andrewsianthus marionensis (S.W.Arnell) Grolle, KC184775.1, -, KC184706.1; Andrewsianthus perigonialis (Hook.f. \& Taylor) R.M.Schust., KC184776.1,-, KC184707.1,-; Barbilophozia atlantica (Kaal.) Müll.Frib.,-,-,,-, AM398349.1; Barbilophozia barbata (Schreb.) Loeske, AM396187, -, JX305536.1, AM398313; Barbilophozia hatcheri (A.Evans) Loeske, KC184777.1, -, DQ312478.1, AM398338.1; Barbilophozia lycopodioides (Wallr.) Loeske, KC184778.1, -, KC297121.1, AM398333.1; Barbilophozia sp., -, -, JX305573.1, JX308594.1; Chaetophyllopsis whiteleggei (Carringt. \& Pears.) Hamlin, -, -, AY462292.1, AY462346.1; Neoorthocalis attenuatus (Mart.) L.Söderstr. \& al., -, -, GU373417.1, -; Neoorthocaulis floerkei (Web. \& Mohr) L.Söderstr. \& al., -,-, KC297118.1,-; Schljakovianthus quadrilobus (Lindb.) Konstant. \& Vilnet, -,-,-, AM398324.1; Sphenolobus minutus (Schreb.) Berggr., -, -, DQ312475.1, JX308554.1. 